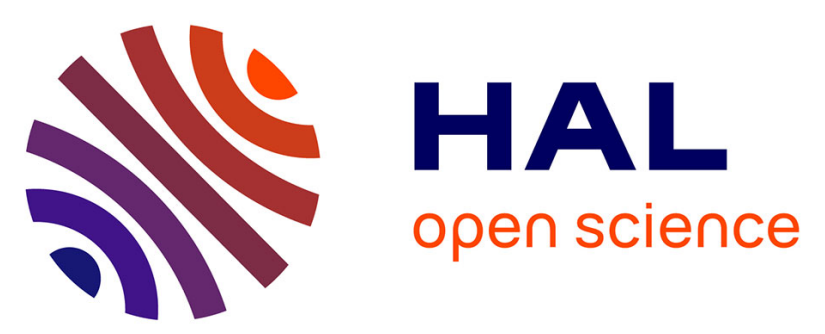

\title{
Isothermal Oxidation Behaviour of NiCoCrAlYTa Coatings Produced by HVOF Spraying and Tribomet ${ }^{\mathrm{TM}}$ Process
}

Raphaël Goti, Marie Bétaille-Francoual, Elodie Hourcastagné, Bernard Viguier, Fabrice Crabos

\section{To cite this version:}

Raphaël Goti, Marie Bétaille-Francoual, Elodie Hourcastagné, Bernard Viguier, Fabrice Crabos. Isothermal Oxidation Behaviour of NiCoCrAlYTa Coatings Produced by HVOF Spraying and Tribomet $^{\text {TM }}$ Process. Oxidation of Metals, 2013, vol. 81 (n $\left.\mathrm{n}^{\circ} 1-2\right)$, pp. 105-113. 10.1007/s11085-0139422-y . hal-01178653

\section{HAL Id: hal-01178653 \\ https://hal.science/hal-01178653}

Submitted on 20 Jul 2015

HAL is a multi-disciplinary open access archive for the deposit and dissemination of scientific research documents, whether they are published or not. The documents may come from teaching and research institutions in France or abroad, or from public or private research centers.
L'archive ouverte pluridisciplinaire HAL, est destinée au dépôt et à la diffusion de documents scientifiques de niveau recherche, publiés ou non, émanant des établissements d'enseignement et de recherche français ou étrangers, des laboratoires publics ou privés. 


\section{OATAO \\ Open Archive Toulouse Archive Ouverte}

Open Archive TOULOUSE Archive Ouverte (OATAO)

OATAO is an open access repository that collects the work of Toulouse researchers and makes it freely available over the web where possible.

This is an author-deposited version published in :

http://oatao.univ-toulouse.fr/

Eprints ID : 14087

To link to this article : DOI:10.1007/s11085-013-9422-y

URL : http://dx.doi.org/10.1007/s11085-013-9422-y

To cite this version : Goti, Raphaël and Bétaille-Francoual, Marie and Hourcastagné, Elodie and Viguier, Bernard and Crabos, Fabrice Isothermal Oxidation Behaviour of NiCoCrAlYTa Coatings Produced by HVOF Spraying and Tribomet ${ }^{\mathrm{TM}}$ Process. (2013) Oxidation of Metals, vol. 81 ( $\left.\mathrm{n}^{\circ} 1-2\right)$. pp. 105-113. ISSN 0030-770X.

Any correspondance concerning this service should be sent to the repository administrator: staff-oatao@listes-diff.inp-toulouse.fr 


\title{
Isothermal Oxidation Behaviour of NiCoCrAIYTa Coatings Produced by HVOF Spraying and Tribomet ${ }^{\mathrm{TM}}$ Process
}

\author{
Raphaël Goti · Marie Bétaille-Francoual • \\ Elodie Hourcastagné • Bernard Viguier • \\ Fabrice Crabos
}

\begin{abstract}
Protective NiCoCrAlYTa coatings are used on gas turbine single crystal superalloy blades to provide environmental resistance. They can be deposited by several processes. In this study, isothermal oxidation behaviour of NiCoCrAlYTa coatings produced by HVOF spraying and Tribomet ${ }^{\mathrm{TM}}$ process and deposited on single crystal nickel-based superalloy CMSX-4 were compared between 950 and $1,150{ }^{\circ} \mathrm{C}$ for several exposure durations. Microstructure and chemical composition of both coatings were examined before and after oxidation testing and quite similar observations were made for both coating processes. The combination of phase and chemical analyses allowed the establishment of an occurrence diagram of phases for both coating processes, according to temperature and duration of exposure. The obtained diagrams seemed similar for both processes. Finally both processes appeared to be equivalent for the protection of CMSX-4 superalloy in isothermal oxidation conditions.
\end{abstract}

Keywords Isothermal oxidation $\cdot \mathrm{MCrAlY} \cdot \mathrm{HVOF}$ spraying $\cdot$ Tribomet $^{\mathrm{TM}}$ process

R. Goti · M. Bétaille-Francoual · E. Hourcastagné · F. Crabos

TURBOMECA-SAFRAN Group, Avenue Joseph Szydlowski, 64511 Bordes Cedex, France

R. Goti $(\bowtie) \cdot$ B. Viguier

Institut Carnot CIRIMAT, INP/ENSIACET, Université de Toulouse, 4 allée Emile Monso,

31030 Toulouse, France

e-mail: raphael.goti@gmail.com

Present Address:

M. Bétaille-Francoual

Herakles-SAFRAN Group, Les 5 Chemins, 33185 Le Haillan, France 


\section{Introduction}

Single crystal nickel-based superalloys are extensively used as turbine blade materials in helicopters, due to their high temperature strength and mechanical properties $[1,2]$. The working environment of gas turbines is extremely severe and operating temperatures range from 900 to $1,150{ }^{\circ} \mathrm{C}$. To improve the single crystal superalloy resistance to high temperature corrosion and oxidation, a protective coating is deposited on the surface of the blades [3, 4]. Diffusion coatings overlay coatings and thermal barrier coatings have been developed to provide the environmental resistance. NiCoCrAlYTa coating is typically used in gas turbines and is more commonly deposited by vacuum plasma spraying and Tribomet $^{\mathrm{TM}}$ process. These MCrAlY coatings have been studied extensively [5-11]. An alternative process is high velocity oxygen fuel (HVOF) spraying [12-14]. The purpose of this paper is to study the deposit of NiCoCrAlYTa coating by HVOF spraying on CMSX-4 superalloy, to analyze its behaviour in terms of oxidation resistance and to compare it with the coating behaviour obtained with Tribomet ${ }^{\mathrm{TM}}$ process.

The behaviour and the environmental resistance properties of NiCoCrAlYTa coatings are linked to their microstructure, thus the follow-up of evolution of the present phases is essential. Consequently microstructure and chemical composition of both coatings, by Tribomet ${ }^{\mathrm{TM}}$ process and by HVOF spraying, were examined before and after oxidation testing. An occurrence diagram of phases and aluminium loss for both coating processes could be established, allowing the identification of the state of degradation of the coating and the changes in nature of the phases.

\section{Materials and Experimental Procedures}

\section{Samples}

The system investigated in this study is the single crystal nickel-based superalloy CMSX-4 coated with NiCoCrAlYTa coating. This alloy is a second generation superalloy developed by Cannon Muskegon, Muskegon, USA for gas turbine applications [15]. Its chemical composition is given in Table 1.

Rectangular coupons $1 \mathrm{~mm}$ thick, $10 \mathrm{~mm}$ wide and $30 \mathrm{~mm}$ long with chamfered edges were spark machined from a CMSX-4 bar solution-treated by Doncasters Precision Castings, Bochum, Germany. Specimens were then coated with $\mathrm{NiCoCr}$ AlYTa coating either by Tribomet ${ }^{\mathrm{TM}}$ process or by HVOF spraying. The average thickness of both NiCoCrAlYTa coatings was between 70 and $90 \mu \mathrm{m}$ depending on specimens. The coating made by the Tribomet ${ }^{\mathrm{TM}}$ process, where CrAlYTa particles are entrapped in a growing $\mathrm{Ni}-\mathrm{Co}$ electroplate layer to produce a uniform dispersion

Table 1 Nominal composition of the CMSX-4 single crystal superalloy used in this study (in wt\%)

\begin{tabular}{llllllllll}
\hline $\mathrm{Ni}$ & $\mathrm{Al}$ & $\mathrm{Co}$ & $\mathrm{Cr}$ & $\mathrm{Hf}$ & $\mathrm{Mo}$ & $\mathrm{Re}$ & $\mathrm{Ta}$ & $\mathrm{Ti}$ & $\mathrm{W}$ \\
\hline Bal. & 5.6 & 9.6 & 6.4 & 0.1 & 0.6 & 3.0 & 6.5 & 1.0 & 6.4 \\
\hline
\end{tabular}


[16], was provided by Praxair Surface Technologies, Oldmixon Crescent, England. The NiCoCrAlYTa coating made by HP/HVOF process [17] was sprayed with a JP5000 system. The nominal composition of NiCoCrAlYTa coatings is given in Table 2.

The heat-treatment consisted of a diffusion treatment during $4 \mathrm{~h}$ at $1,100{ }^{\circ} \mathrm{C}$ in low pressure argon atmosphere.

\section{Isothermal Oxidation Tests and Observation}

Isothermal oxidation tests were performed in laboratory air environment on both types of coating deposited on specimens at different temperatures between 950 and $1,150{ }^{\circ} \mathrm{C}$, for different exposure times $(4,25,100$ and $900 \mathrm{~h}$ ) depending on temperature. The different conditions tested in this study are listed in Table 3. Specimens were then examined on polished cross-sections. Both optical and scanning electron microscopy (SEM) with X-ray energy-dispersive spectroscopy (XEDS) studies were carried out before and after each oxidation testing. Attention has been paid to the evolution of microstructure and the consumption of aluminium from the as-coated condition through to subsequent thermal exposure.

\section{Results and Discussion}

\section{Comparison of Coating Processes After Full Heat Treatment}

The resulting microstructures of NiCoCrAlYTa coatings, by Tribomet $^{\mathrm{TM}}$ process and HVOF spraying, after heat-treatment, are shown in Fig. 1a, b) respectively. Cohesion of the coatings with the substrate is strong and no macrocracks were found. The composition of the coating deposited by HVOF spraying is homogeneous because molten NiCoCrAlYTa powder is projected through a flame at supersonic speed onto the substrate. On the other hand, the composition of the coating produced by Tribomet ${ }^{\mathrm{TM}}$ process is locally heterogeneous even after the

Table 2 Composition of NiCoCrAlYTa coatings (in wt $\%$ )

\begin{tabular}{lllllll}
\hline & $\mathrm{Ni}$ & $\mathrm{Co}$ & $\mathrm{Cr}$ & $\mathrm{Al}$ & $\mathrm{Y}$ & Ta \\
\hline HVOF & Bal. & 23 & 20 & 8.5 & 0.6 & 4.5 \\
Tribomet $^{\mathrm{TM}}$ & Bal. & 24 & 19 & 8 & 0.4 & 4.5 \\
\hline
\end{tabular}

Table 3 Conditions of exposure temperature and time on NiCoCrAlYTa coatings

\begin{tabular}{lccccc}
\hline $\begin{array}{l}\text { Temperature } \\
\left({ }^{\circ} \mathrm{C}\right)\end{array}$ & 950 & 1,000 & 1,050 & 1,100 & 1,150 \\
\hline Time (h) & 100 and & $\begin{array}{c}25,100 \text { and } \\
900\end{array}$ & $\begin{array}{c}25,100 \text { and } \\
900\end{array}$ & $\begin{array}{c}4,25,100 \text { and } \\
900\end{array}$ & $\begin{array}{c}4,25 \text { and } \\
100\end{array}$ \\
\hline
\end{tabular}




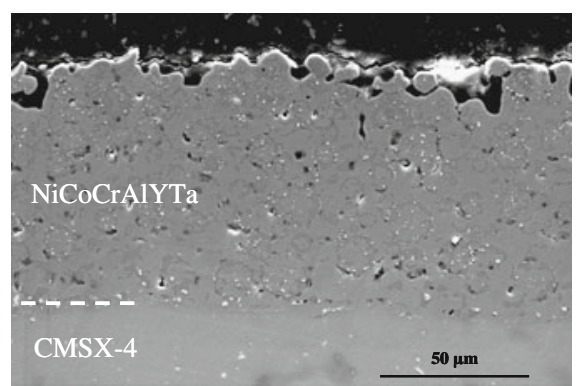

(a)

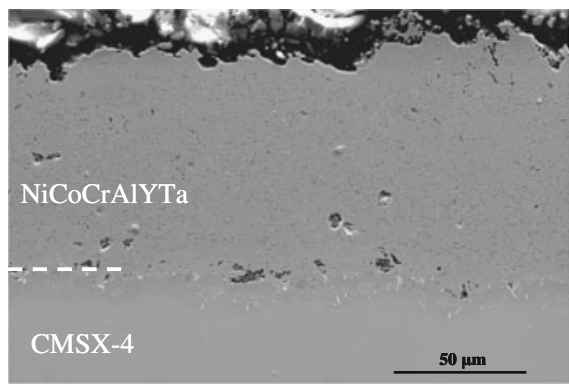

(b)

Fig. 1 SEM image of NiCoCrAlYTa coating deposited by Tribomet ${ }^{\mathrm{TM}}$ process (a) and HVOF spraying (b) on CMSX-4 superalloy after full heat treatment

diffusion treatment because CrAlYTa particles in suspension in NiCo solution are deposited during the process. Consequently the particles are trapped in the matrix. Moreover the phases present have different structures in both coatings: indeed, the structure is fine with HVOF spraying and coarser with Tribomet ${ }^{\mathrm{TM}}$ process.

\section{Microstructures After Isothermal Oxidation Tests}

The microstructure of the NiCoCrAlYTa coating consists of $\beta$-NiAl (B2 structure) and $\gamma^{\prime}-(\mathrm{Ni}, \mathrm{Cr})_{3} \mathrm{Al}\left(\mathrm{L1}_{2}\right.$ structure $)$ islands in a $\gamma$ matrix $(\mathrm{Ni}, \mathrm{Co}, \mathrm{Cr}$ rich phase with fcc structure). Moreover Ta- (and Ti-) rich precipitates can be observed in both coatings. The phases and particles present are illustrated in Fig. 2, after $100 \mathrm{~h}$ isothermal exposure at $950{ }^{\circ} \mathrm{C}$ for both coatings (a: Tribomet ${ }^{\mathrm{TM}}$ process, b: HVOF spraying). One can also observe dark particles which are oxides dispersed in the microstructure, principally in NiCoCrAlYTa coating deposited by HVOF spraying.

During NiCoCrAlYTa coating oxidation, grains of aluminium-rich $\beta$ phase gradually convert to islands of $\gamma^{\prime}$ phase and then to $\gamma$ phase by consumption of the aluminium. This is due to both the formation of the oxide scale and, near the coating/superalloy interface, the interdiffusion with the substrate, as shown in Fig. 3 for an isothermal oxidation test on sample coated by HVOF spraying after $100 \mathrm{~h}$ at $950{ }^{\circ} \mathrm{C}$. As a result of the decrease of the aluminium content, the depletion of the $\beta$-NiAl phase then of the $\gamma^{\prime}$ phase occurs in the coating.

The microstructures and phases of the oxidized coatings depend on the exposure temperature and duration, as shown in Table 4. After treatments at lowest temperatures and times, coatings are three-phased, whereas after treatments at highest temperatures, coatings are converted fully to a single $\gamma$ phase during the oxidation duration. For intermediate conditions, two-phased microstructures are observed. Present phases are very similar for both NiCoCrAlYTa coatings for all the conditions, except at $1,050{ }^{\circ} \mathrm{C}$ during $900 \mathrm{~h}$. One can notice that $\gamma^{\prime}$ phase is only present at $950,1,000$ and $1,050{ }^{\circ} \mathrm{C}$ because at higher temperatures, its stability domain is reduced in favor of $\beta$ and $\gamma$ phases. These results are in agreement with the $\mathrm{Ni}-\mathrm{Cr}-\mathrm{Al}$ ternary phase diagram of Taylor and Floyd [18]. To determine the average aluminium content, three measures by XEDS have been performed on the 


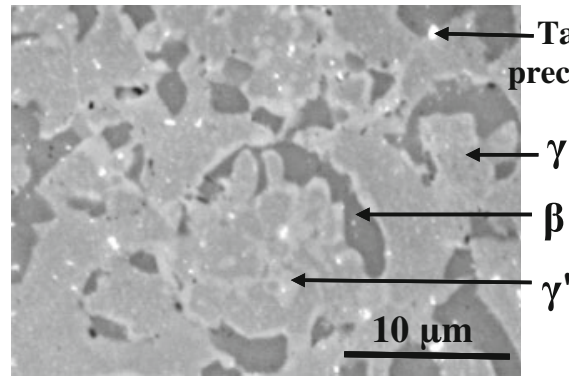

(a)

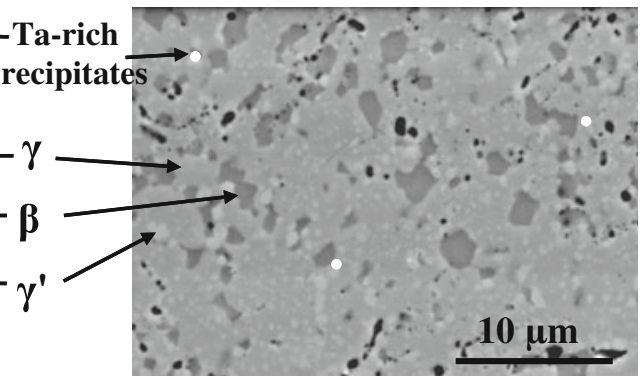

(b)

Fig. 2 SEM image of present phases in NiCoCrAlYTa coating deposited by Tribomet ${ }^{\mathrm{TM}}$ process (a) and HVOF spraying (b) on CMSX-4 superalloy after $100 \mathrm{~h}$ isothermal exposure at $950{ }^{\circ} \mathrm{C}$

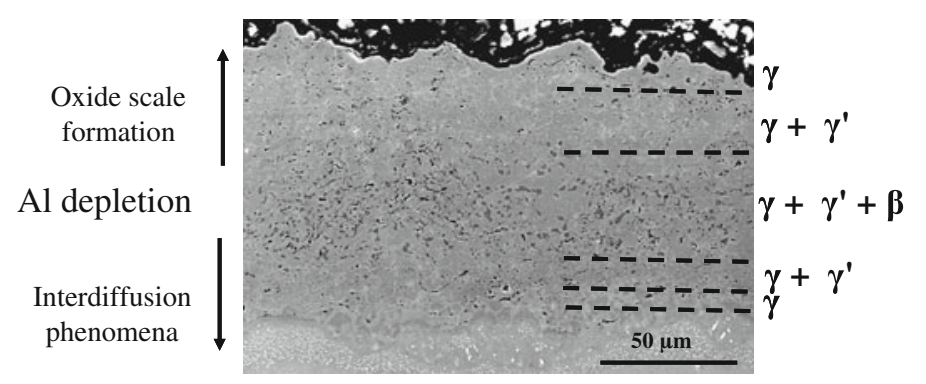

Fig. 3 Al depletion in NiCoCrAlYTa coating deposited by HVOF spraying, after isothermal oxidation test during $100 \mathrm{~h}$ at $950{ }^{\circ} \mathrm{C}$

whole coating thickness of each tested sample. The consumption of aluminium increases during long times of exposure and at high temperatures. Moreover it seems that, for constant temperature, aluminium content is decreasing more slowly with exposure duration in the case of HVOF coating than for Tribomet ${ }^{\mathrm{TM}}$ coating. The combination of these results allows the establishment of an occurrence diagram of phases, shown in Fig. 4, and quite similar to that obtained in [8]. This diagram characterizes the microstructure of the coating according to temperature and time of exposure. It allows the identification of the state of degradation of the coating.

One can consider that NiCoCrAlYTa coating has a protective effect on CMSX-4 superalloy in the domains with three phases $\beta / \gamma / \gamma^{\prime}$ or two phases $\beta / \gamma$ or $\gamma / \gamma^{\prime}$. On the other hand, during long time at 1,100 and $1,150{ }^{\circ} \mathrm{C}$, the microstructure is single phased $\gamma$ for both coating processes. During isothermal oxidation tests, the NiCoCrAlYTa coating microstructure diagram is very similar for Tribomet ${ }^{\mathrm{TM}}$ process and HVOF spraying.

Ta-rich precipitates are observed in both coatings, particularly when the temperature is lower than $1,100{ }^{\circ} \mathrm{C}$ since the coating is then rich in $\beta$ phase. Indeed $\mathrm{Ta}$ is not very soluble in $\beta$ phase. At 1,100 and $1,150{ }^{\circ} \mathrm{C}$, the precipitates dissolve because the coating is rapidly converted to $\gamma$ single-phased. Moreover Ta-rich precipitates are also observed at the coating/substrate interface. During long 
Table 4 Exposure temperature and time dependence of NiCoCrAlYTa coatings microstructure

\begin{tabular}{|c|c|c|c|c|c|}
\hline \multirow[t]{2}{*}{ Temperature $\left({ }^{\circ} \mathrm{C}\right)$} & \multirow{2}{*}{ Exposure time (h) } & \multicolumn{2}{|l|}{ Phases } & \multicolumn{2}{|c|}{ Aluminium content (wt $\%$ ) } \\
\hline & & Tribomet $^{\mathrm{TM}}$ & HVOF & Tribomet $^{\mathrm{TM}}$ & HVOF \\
\hline \multirow[t]{2}{*}{950} & 100 & $\beta / \gamma / \gamma^{\prime}$ & $\beta / \gamma / \gamma^{\prime}$ & 7.2 & 6.9 \\
\hline & 900 & $\gamma / \gamma^{\prime}$ & $\gamma / \gamma^{\prime}$ & 5.8 & 6.6 \\
\hline \multirow[t]{3}{*}{1,000} & 25 & $\beta / \gamma / \gamma^{\prime}$ & $\beta / \gamma / \gamma^{\prime}$ & 7.6 & 7.7 \\
\hline & 100 & $\beta / \gamma / \gamma$ & $\beta / \gamma / \gamma^{\prime}$ & 6.4 & 6.5 \\
\hline & 900 & $\gamma / \gamma^{\prime}$ & $\gamma / \gamma^{\prime}$ & 5.3 & 5.7 \\
\hline \multirow[t]{3}{*}{1,050} & 25 & $\beta / \gamma$ & $\beta / \gamma / \gamma^{\prime}$ & 6.7 & 7.5 \\
\hline & 100 & $\gamma / \gamma^{\prime}$ & $\gamma / \gamma^{\prime}$ & 5.6 & 5.7 \\
\hline & 900 & $\gamma$ & $\gamma / \gamma^{\prime}$ & 4.9 & 5.2 \\
\hline \multirow[t]{4}{*}{1,100} & 4 & $\beta / \gamma$ & $\beta / \gamma$ & 8.3 & 8.2 \\
\hline & 25 & $\beta / \gamma$ & $\beta / \gamma$ & 5.7 & 6.7 \\
\hline & 100 & $\gamma$ & $\gamma$ & 5.1 & 5.4 \\
\hline & 900 & $\gamma$ & $\gamma$ & 4.5 & 5.0 \\
\hline \multirow[t]{3}{*}{1,150} & 4 & $\beta / \gamma$ & $\beta / \gamma$ & 6.4 & 7.1 \\
\hline & 25 & $\gamma$ & $\gamma$ & 5.5 & 5.7 \\
\hline & 100 & $\gamma$ & $\gamma$ & 4.9 & 5.2 \\
\hline
\end{tabular}

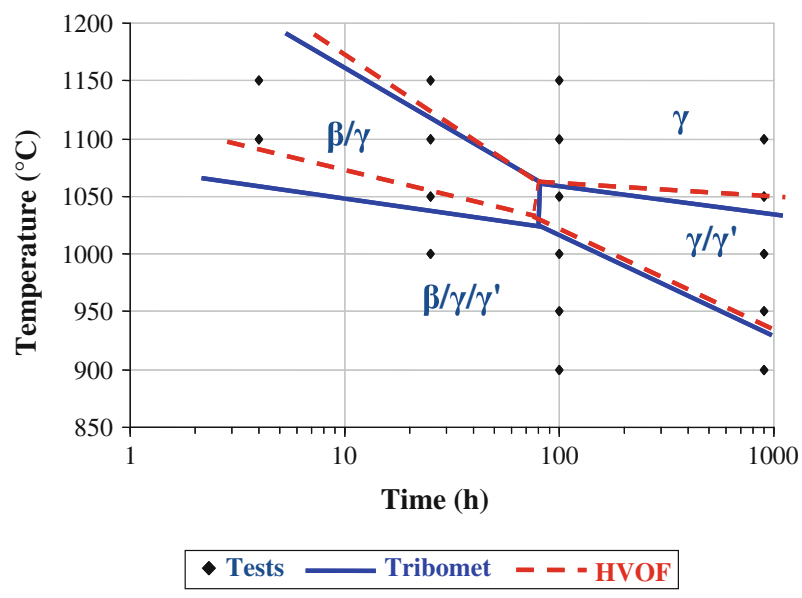

Fig. 4 Coating microstructure diagram, function of temperature and exposure duration

times of exposure and at high temperatures they grow as cuboids. They enrich with $\mathrm{Ti}$ from substrate because of interdiffusion phenomena. Ta traps $\mathrm{Ti}$ and thus inhibits the formation of $\mathrm{TiO}_{2}$ that is less protective than alumina scale [7, 19, 20]. Ta-rich precipitates are slightly more abundant in NiCoCrAlYTa coating deposited by Tribomet $^{\mathrm{TM}}$ process than by HVOF spraying.

In both NiCoCrAlYTa coatings, alumina and other oxides (Cr- or Y-rich) are also dispersed, as illustrated by Fig. 5 after isothermal oxidation test at $1,000{ }^{\circ} \mathrm{C}$ during 


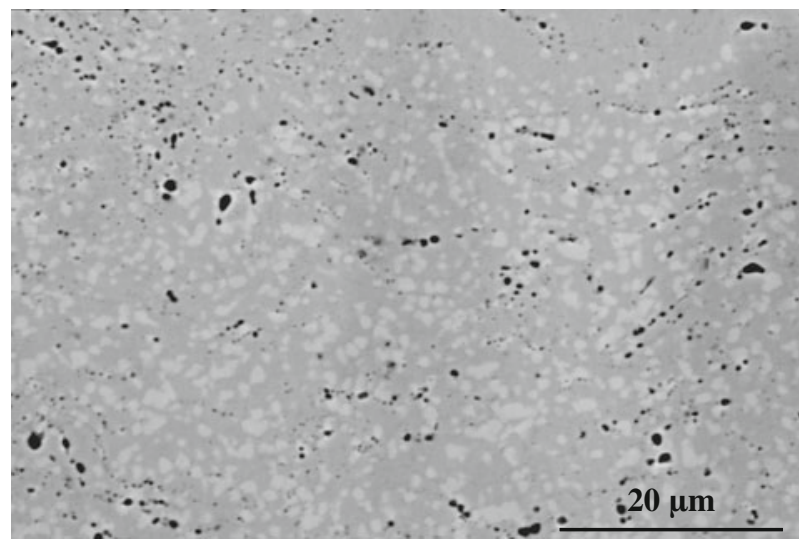

Fig. 5 Dispersion of oxides (black particles) in NiCoCrAlYTa coating deposited by HVOF spraying after $900 \mathrm{~h}$ exposure at $1,000{ }^{\circ} \mathrm{C}$

900 h on NiCoCrAlYTa coating by HVOF spraying. However they are much more abundant in NiCoCrAlYTa coating deposited by HVOF spraying because NiCoCr AlYTa particles can oxidize during the projection of powder in flame. The size of oxides is quite small and they are arranged in chains. These small oxides can have a beneficial effect on mechanical properties of NiCoCrAlYTa coating in reinforcing it with hardening particles. Their small size prevents a possible embrittlement of NiCoCrAlYTa coating. According to Toma et al. [14], this fine oxide dispersion could also have a beneficial effect on the high-temperature oxidation behaviour in promoting the fast formation of protective $\alpha-\mathrm{Al}_{2} \mathrm{O}_{3}$ on $\mathrm{HVOF} \mathrm{MCrAlY}$ coatings. Small porosities were also observed in both coating processes.

Consequently NiCoCrAlYTa coatings deposited by both processes are quite similar after isothermal oxidation tests in terms of microstructure and phase evolution. NiCoCrAlYTa coating degradation seems roughly equivalent according to coating microstructure diagram. But this diagram is not the only criterion of coating degradation and protection degree.

Comparison of Aluminium Loss between both Coating Processes

The follow-up of aluminium lost is also fundamental because aluminium is a protective element of the NiCoCrAlYTa coating. In fact, a large Al reservoir is beneficial for the formation of a protective alumina scale. The quantity of aluminium is calculated by (1) [21]:

$$
\text { Quantity }\left(\mathrm{mg} \mathrm{cm}^{-2}\right)=d_{\text {NiCoCrAlYTa }} \times t_{\text {NiCoCrAlYTa }} \times \mathrm{Al} \% \text { mass } / 100
$$

where $d_{\mathrm{NiCoCrAlYTa}}$ is coating density, $t_{\mathrm{NiCoCrAlYTa}}$ is coating thickness and $\mathrm{Al} \%$ mass is coating content of aluminium. The value of coating density is calculated by using empirical formula of Hull [22], applicable for superalloys, and is equal to $7.7 \mathrm{~g} \mathrm{~cm}^{-3}$ in this study. $t_{\mathrm{NiCoCrAlYTa}}$ is the average measure of coating thickness on all the samples of a coating process tested in this study and is equal to $78 \mu \mathrm{m}$ for 


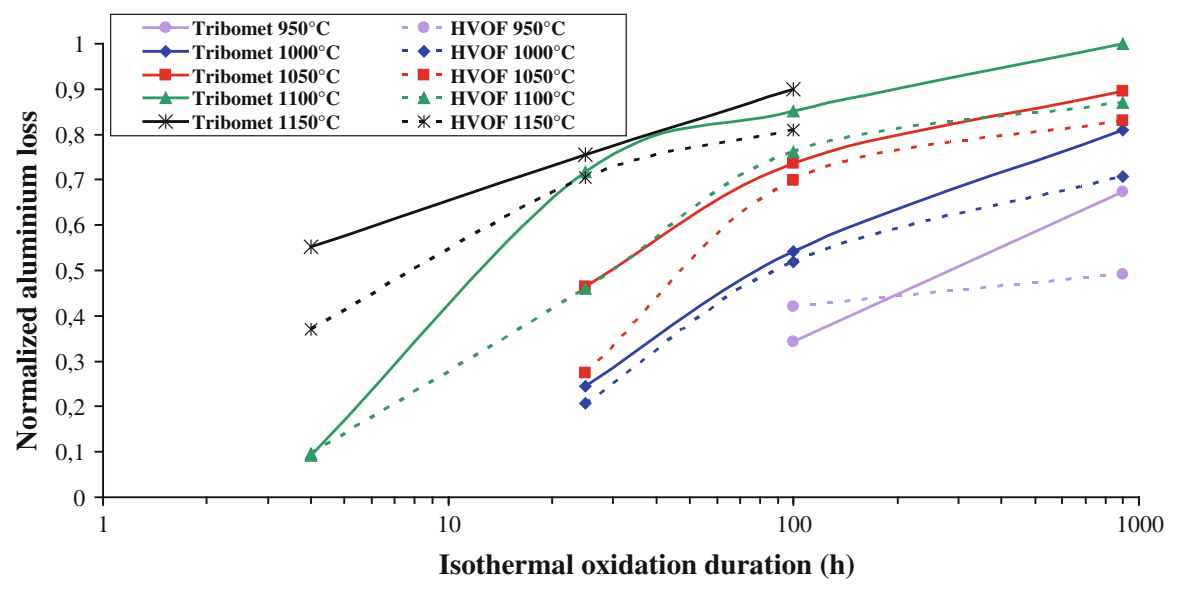

Fig. 6 Evolution of aluminium loss in function of exposure duration

HVOF spraying and $75 \mu \mathrm{m}$ for Tribomet ${ }^{\mathrm{TM}}$ process. Therefore the loss of aluminium is estimated by (2):

$$
\text { Al loss (\%) }=\frac{\text { Quantity (ref) }- \text { Quantity }}{\text { Quantity (ref) }}
$$

The aluminium loss has been determined for both coating processes and has been used to construct Fig. 6 where normalized aluminium loss (compared with the maximal aluminium loss of this study obtained at $1,100{ }^{\circ} \mathrm{C}$ and after $900 \mathrm{~h}$ with Tribomet $^{\mathrm{TM}}$ process) is plotted as a function of isothermal oxidation duration.

For all the tested temperatures aluminium loss is large and fast during the first $100 \mathrm{~h}$ (conversion of $\beta$ and $\gamma$ ' phases in $\gamma$ phase and $\alpha-\mathrm{Al}_{2} \mathrm{O}_{3}$ scale formation) then decreases strongly since aluminium depletion is a phenomenon controlled by interdiffusion and oxide scale formation. The consumption of aluminium increases with high temperature and exposure time since interdiffusion and oxidation are thermally activated phenomena. For all the tested temperatures, aluminium loss after $900 \mathrm{~h}$ is slightly larger for NiCoCrAlYTa coating deposited by Tribomet ${ }^{\mathrm{TM}}$ process than by HVOF spraying. These results confirm that NiCoCrAlYTa coatings deposited by both processes are quite equivalent in terms of isothermal oxidation resistance at high temperatures. Results obtained in cyclic oxidation/corrosion but not presented in this paper show also equivalence between both processes [23].

\section{Conclusions}

In this study, the deposit of NiCoCrAlYTa coating by HVOF spraying on CMSX-4 has been analyzed. Firstly the coating obtained after spraying and full heattreatment presents a fine and homogeneous structure whereas the structure is coarser and less homogeneous with the same NiCoCrAlYTa coating deposited by Tribomet $^{\mathrm{TM}}$ process. Both coatings have the same composition and phases. 
Moreover isothermal oxidation tests performed on both coatings between 950 and $1,150{ }^{\circ} \mathrm{C}$ showed that coatings deposited by HVOF spraying and by Tribomet ${ }^{\mathrm{TM}}$ process exhibit similar behaviours. Indeed microstructural evolution of both coatings is identical, as shown by both diagrams of occurrence of phases that are roughly equivalent. Furthermore, during isothermal oxidation tests performed in this study, NiCoCrAlYTa coating by HVOF spraying exhibits aluminium loss of similar magnitude (even lower) than those obtained with NiCoCrAlYTa coating deposited by Tribomet ${ }^{\mathrm{TM}}$ process. Similarly to this last well-known NiCoCrAlYTa coating, NiCoCrAlYTa coating obtained by HVOF spraying shows thus high protection for CMSX-4 superalloy in isothermal oxidation and HVOF spraying seems to represent a good alternative process for NiCoCrAlYTa coating deposit.

Acknowledgments This work is supported by Turbomeca-SAFRAN group. The authors wish to acknowledge Dr Aurélie Rouaix-Vande Put from Institut Carnot-CIRIMAT, France, for her help with preliminary work and stimulating discussions, and Florian Kerguen and Geoffrey Bégué-Duthu for performing preliminary works.

\section{References}

1. R. C. Reed, The Superalloys-Fundamentals and Applications, (Cambridge University Press, Cambridge, 2006).

2. P. Caron and T. Khan, Aerospace Science and Technology 3, 513 (1999).

3. D. S. Rickerby and M. R. Winstone, Materials and Manufacturing Processes 7, (4), 495 (1992).

4. J. T. DeMasi-Marcin and D. K. Gupta, Surface and Coatings Technology 68-69, 1 (1994).

5. Mevrel, and R. Morbioli, in Proceeding First International Congress (High-Techn-Materials and Finishing, Berlin, 1989).

6. A. Boudot, Propriétés des revêtements de protection haute température pour pales de turbine haute pression, PhD Thesis, Institut National Polytechnique de Toulouse (1997).

7. T. A. Taylor and D. F. Bettridge, Surface and Coatings Technology 86/87, 9 (1996).

8. A. Raffaitin, F. Crabos, E. Andrieu and D. Monceau, Surface and Coatings Technology 201, 3829 (2006).

9. F. J. Belzunce, V. Higuera and S. Poveda, Materials Science and Engineering A297, 162 (2001).

10. M. J. Pomeroy, Materials and Design 26, 223 (2005).

11. A. Vande Put, D. Oquab, E. Péré, A. Raffaitin and D. Monceau, Oxidation of Metals 75, 247 (2011).

12. W. Brandl, D. Toma, J. Krüger, H. J. Grabke and G. Matthaüs, Surface and Coatings Technology 94-95, 1997 (21).

13. L. Russo, and M. Dorfman, in Proceedings of ITSC'95 (Kobe, Japan, 1995).

14. D. Toma, W. Brandl and U. Köster, Surface and Coatings Technology 120-121, 8 (1999).

15. K. Harris, G. L. Erickson, S. L. Sikkenga, W. D. Brentnall, J. M. Aurrecoechea, and K. G. Kubarych, in Superalloys 1992, eds. S. D. Antolovich et al., (TMS, Warrendale, 1992), p. 297.

16. T. Taylor and J. Foster, Surface and Coatings Technology 201, (7), 3819 (2006).

17. J. Koutsky, Journal of Materials Processing Technology 157, 557 (2004).

18. A. Taylor and R. W. Floyd, Journal of the Institute of Metals 81, 451 (1952-1953).

19. R. Mévrel, Materials Science and Engineering A 120, 13 (1989).

20. P. Fox and G. J. Tatlock, Materials Science and Technology A 5, 816 (1989).

21. A. Raffaitin, Influence du cyclage thermique sur les comportements en oxidation/corrosion et en fluage de systèmes MCrAlY/superalliage à base de nickel, PhD Thesis, Institut National Polytechnique de Toulouse, ENSIACET/CIRIMAT, France (2007).

22. F. D. Hull, Metal Progress 96, (5), 139 (1969).

23. E. Hourcastagné, Qualification du revêtement NiCoCrAlYTa appliqué par HVOF, Internal Technical Note No. AA073676 (Turbomeca, 2012). 